\title{
Response of arbuscular mycorrhizal fungal community in soil and roots to grazing differs in a wetland on the Qinghai-Tibet plateau
}

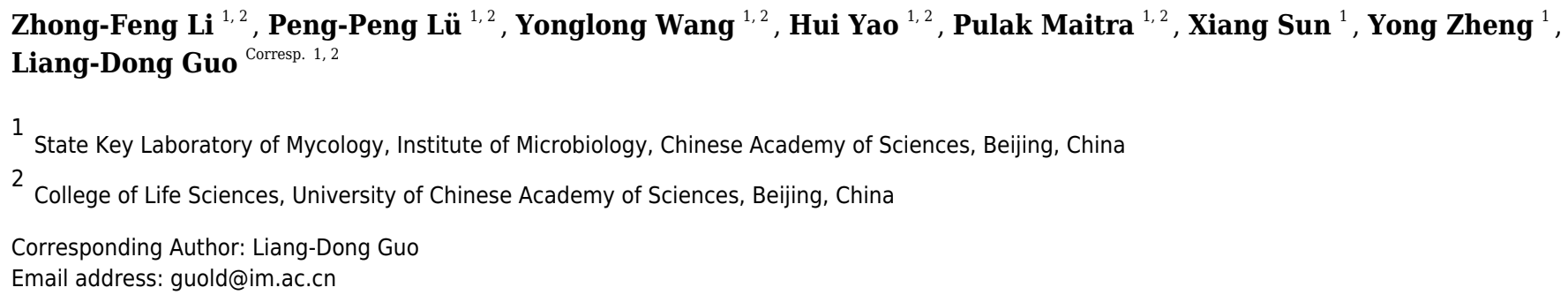

Grazing as one of the most important disturbances affects the abundance, diversity and community composition of arbuscular mycorrhizal (AM) fungi in ecosystems, but the AM fungi in response to grazing in wetland ecosystems remain poorly documented. Here, we examined AM fungi in roots and soil in grazing and non-grazing plots in Zoige wetland on the Qinghai-Tibet plateau. Grazing significantly increased AM fungal spore density and glomalin-related soil proteins, but had no significant effect on the extra radical hyphal density of AM fungi. While AM fungal richness and community composition differed between roots and soil, grazing was found to influence only the community composition in soil. This study shows that moderate grazing can increase the biomass of AM fungi and soil carbon sequestration, and maintain the AM fungal diversity in the wetland ecosystem. This finding may enhance our understanding of the AM fungi in response to grazing in the wetland on the Qinghai-Tibet plateau. 
1 Response of arbuscular mycorrhizal fungal community in soil and roots to grazing differs

2 in a wetland on the Qinghai-Tibet plateau

3

4 Zhong-Feng Li ${ }^{1,2}$, Peng-Peng Lü ${ }^{1,2}$, Yong-Long Wang ${ }^{1,2}$, Hui Yao ${ }^{1,2}$, Pulak Maitra ${ }^{1,2}$, Xiang Sun ${ }^{1}$,

5 Yong Zheng ${ }^{1}$, Liang-Dong Guo ${ }^{1,2, *}$

$6{ }^{1}$ State Key Laboratory of Mycology, Institute of Microbiology, Chinese Academy of Sciences,

7 Beijing 100101, China

$8{ }^{2}$ College of Life Sciences, University of Chinese Academy of Sciences, Beijing 100049, China

9 * Corresponding author: guold@im.ac.cn (L.D. Guo) 
10 ABSTRACT

11

12 Grazing as one of the most important disturbances affects the abundance, diversity and 13 community composition of arbuscular mycorrhizal (AM) fungi in ecosystems, but the AM fungi 14 in response to grazing in wetland ecosystems remain poorly documented. Here, we examined

15 AM fungi in roots and soil in grazing and non-grazing plots in Zoige wetland on the Qinghai16 Tibet plateau. Grazing significantly increased AM fungal spore density and glomalin-related soil 17 proteins, but had no significant effect on the extra radical hyphal density of AM fungi. While

18 AM fungal richness and community composition differed between roots and soil, grazing was 19 found to influence only the community composition in soil. This study shows that moderate 20 grazing can increase the biomass of AM fungi and soil carbon sequestration, and maintain the

21 AM fungal diversity in the wetland ecosystem. This finding may enhance our understanding of 22 the AM fungi in response to grazing in the wetland on the Qinghai-Tibet plateau.

24 Keywords: Arbuscular mycorrhizal fungal abundance, Community, Diversity, Grazing, Wetland 
26

\section{INTRODUCTION}

Wetlands cover about $6 \%$ of the land surface on the earth and have high species diversity, including many endemic species (Junk et al., 2013). In China, wetlands account for $7 \%$ of the wetland on the world (Junk et al., 2013) and have about 225 families, 815 genera and 2,276 species of higher plants (Yan \& Zhang, 2005). Wetlands provide important ecological functions in water resource conservation and quality purification, climate regulation, substance circulation and regional ecological balance maintenance (Green et al., 2017). Moreover, as an important carbon (C) pool, wetlands can reduce the impact of increased greenhouse gases on global climate change (Frolking et al., 2011). However, wetland ecosystems have suffered severe degradations in recent decades due to global warming, intense resource exploitation, changes in hydrology and human disturbance (Xiang et al., 2009; Junk et al., 2013). For example, over-grazing as one of the most important human activities, has affected biodiversity, productivity, community stability and soil C cycling in wetlands (Hoffmann et al., 2016; Zhou et al., 2017).

Arbuscular mycorrhizal (AM) fungi, as one of the key components of soil microorganisms, form symbiotic associations with most terrestrial plant species (Smith \& Read, 2008). In the AM associations, plants provide $\mathrm{C}$ source for the growth and function of fungi, thereby affecting the community of AM fungi (Smith \& Read, 2008). In return, AM fungi can increase the nutrient and water absorption of host plants through formation of underground fungal hyphal networks, then affecting plant community and productivity (van der Heijden, Bardgett \& van Straalen, 2008). Furthermore, AM fungal hyphal and spores produce glomalin-related soil protein (GRSP) which can stably exist in soil and play an important role in soil C pool (Godbold et al., 2006). In addition, AM fungi can improve plants to tolerate grazing and other stresses from the 
48

49

50

51

52

53

54

environment (Bennett \& Bever, 2007). Thus, revealing the AM fungi in response to grazing is of great importance for understanding the diversity maintenance and community stability of plants in ecosystems, especially in wetland ecosystems.

Previous studies have demonstrated that the effect of grazing on AM fungi is depended on grazing intensity (García \& Mendoza, 2012; Kusakabe et al., 2018; Yang et al., 2019). For instance, the light and moderate grazing intensity positively influenced AM fungal spore density in grasslands in Jilin province, China (Ba et al., 2012) and in British Columbia, Canada (van der Heyde et al., 2017). In contrast, over-grazing negatively affected AM fungal spore density in a semi-arid grassland in China ( $\mathrm{Su} \& \mathrm{Guo}, 2007)$. Moderate grazing intensity did not influence AM fungal extra radical hyphal density in an alpine meadow in China (Yang et al., 2013), but high grazing pressure negatively affected the extra radical hyphal density of AM fungi in a semiarid grassland in China (Ren et al., 2018). Besides, moderate grazing had a neutral effect on AM fungal richness in a meadow in China (Ba et al., 2012). Moderate grazing significantly affected the community composition of AM fungi in soil and roots in grassland ecosystems (Bai et al., 2013; Yang et al., 2013; Kusakabe et al., 2018). In contrast, others found that moderate grazing did not influence the community composition of AM fungi in roots in alpine meadow (Jiang et al., 2018) and in soil in mountain grassland (van der Heyde et al., 2017) ecosystems. However, previous studies have mainly focused on semi-arid, arid, alpine and mountain grassland ecosystems. So far, we know little about how grazing affects AM fungi in wetland ecosystems.

Zoige wetland is a typical representative of the alpine wetland ecosystem on the QinghaiTibet plateau in China, and has high plant species diversity and an important $\mathrm{C}$ sink function (Guo et al., 2013). However, Zoige wetland has suffered severe ecosystem degradations since the 1970s, due to global warming, low precipitation and human disturbance, such as ditching for 
71 grassland enlargement, peat exploitation and over-grazing (Xiang et al., 2009; Guo et al., 2013).

72 Previous studies have mainly focused on plant diversity, microbial community (archaea group),

73 and ecosystem conservation and restoration in the Zoige Wetland (Wang, Bao \& Yan, 2002;

74 Xiang et al., 2009). However, the grazing effect on AM fungi has never been studied.

Overall, the effects of intense grazing on mycorrhizal symbiosis may lead to a shortage on

$\mathrm{C}$ from the plant to the fungi, what has been related to fungal response with a different production of glomalin and spores and extra radical hyphae of fungal biomass (Hammer \& Rillig, 2011; Ba et al., 2012; van der Heyde et al., 2017). Besides, grazing may cause changes in AM fungal richness and community composition in plant roots and surrounding soil (Bai et al., 2013; Yang et al., 2013). However, these responses are environmentally dependent and habitatsensitive and may be influenced by soil characteristics and dynamics (Ren et al., 2018; Yang et al., 2019). This study represents the first one to analyze AM fungal responses to grazing in wetland ecosystems. established non-grazing (natural) and moderate grazing plots in Zoige wetland on the QinghaiTibet plateau. AM fungal spore density, extra radical hyphal density and GRSP content were examined in grazing and non-grazing plots. We examined the communities of AM fungi in roots and soil by Illumina MiSeq sequencing of $18 \mathrm{~S}$ rDNA region. We aimed to explore the effect of moderate grazing on AM fungal spore density, extra radical hyphal density, GRSP content, richness and community composition in the Zoige wetland. 
94

95

96

97

98

\section{Study site and sampling}

The study was carried out in the centre of Zoige Swamp in the Zoige National Nature Reserve on the Qinghai-Tibet plateau $\left(33^{\circ} 25^{\prime}-34^{\circ} 80^{\prime} \mathrm{N}, 102^{\circ} 29^{\prime}-102^{\circ} 59^{\prime} \mathrm{E}, 16,671\right.$ ha, $3365 \mathrm{~m}$ above sea level). The site has a plateau cold temperate humid monsoon climate, with a mean annual temperature (MAT) of $1.1^{\circ} \mathrm{C}$, and a mean annual precipitation (MAP) of $660 \mathrm{~mm}$ (Wang, Bao \& Yan, 2002). The site begins to freeze in late September and is completely thawed in midMay (Wang, Bao \& Yan, 2002). The abundant plant species are Blysmus sinocompressus, Potentilla anserina, Carex enervis, Caltha scaposa, Elymus nutans and Leontopodium wilsonii in the site (Wang, Bao \& Yan, 2002).

The Sichuan Zoige Wetland National Nature Reserve Authority approved the collection of soil and root samples in the Zoige Wetland National Nature Reserve. We established 20 plots (each $1 \mathrm{~m} \times 1 \mathrm{~m}),>20 \mathrm{~m}$ away from each other, in non-grazing (natural grass) and grazing area, respectively (Supplementary Fig. S1). The average species number and height of vegetation were $7.8 \pm 0.495($ mean $\pm \mathrm{SE}$ ) and $c a .31 \mathrm{~cm}$ in the non-grazing plots and $5.4 \pm 0.255$ and $\mathrm{ca} .7 \mathrm{~cm}$ in the grazing plots. This site was mainly grazed by yaks from June to September, as the growing season is from May to August. The grazing intensity ( $c a .1 .8 \mathrm{yak} / \mathrm{ha}$ ) in this study site was described as moderate, as previous study showed that there are three different grazing intensities by yaks (light: 1.2 yaks/ha, moderate: 2.0 yaks/ha, and heavy: 2.9 yaks/ha) in alpine meadow on the eastern Tibetan Plateau (Gao et al., 2007). In July 2018, with the best vegetation growth stage, we randomly collected five soil cores $(3 \mathrm{~cm}$ in diameter; $15 \mathrm{~cm}$ in depth; $c a .300 \mathrm{~g})$ and mixed into one composite sample from each plot. A total of 40 samples were obtained, packed in an ice box and transported to our laboratory. Soil samples were sieved (1-mm sieve) to remove debris and roots. Subsoil samples were kept at $-80{ }^{\circ} \mathrm{C}$ until the extraction of fungal hyphae and 
117 DNA, and the remaining subsoil samples were air dried and kept at $10{ }^{\circ} \mathrm{C}$ until the analysis of

118 AM fungal spore density, GRSP content and soil properties. We manually collected the mixed 119 roots $(<2 \mathrm{~mm}$ in diameter) from each sieved root sample, washed with sterilized deionized water 120 and kept at $-80{ }^{\circ} \mathrm{C}$ until DNA extraction.

\section{Soil property analysis}

We weighed a certain amount of soil from each sample before and after drying for 24 hours in an oven at $105^{\circ} \mathrm{C}$, then calculated the percentage of soil moisture. Soil $\mathrm{pH}$ was measured at a ratio of 1:2.5 (w/v, soil: water) with a glass electrode (Thermo Orion T20, Columbia, USA). Soil total nitrogen $(\mathrm{N})$ and $\mathrm{C}$ were determined by CHNOS Elemental Analyser (Vario EL III Elementar Analysensysteme GmbH, Germany). Soil total phosphorus (P) was extracted using the $\mathrm{HClO}_{4}-\mathrm{H}_{2} \mathrm{SO}_{4}$ digestion method and determined with a spectrophotometer (UV-2550, Shimadzu, Japan).

\section{EE-GRSP and T-GRSP}

Total GRSP (T-GRSP) and easily extracted GRSP (EE-GRSP) were measured according to the method of Janos et al. (2008). We extracted EE-GRSP from $0.1 \mathrm{~g}$ air dried soil using sodium citrate buffer $(8 \mathrm{~mL}, 0.02 \mathrm{M}, \mathrm{pH} 7.0)$ at $121^{\circ} \mathrm{C}$ for $90 \mathrm{~min}$ in an autoclave (Yamato SQ810C, China). We repeatedly extracted T-GRSP from $0.1 \mathrm{~g}$ air dried soil using sodium citrate buffer (8 $\mathrm{mL}, 0.05 \mathrm{M}, \mathrm{pH} 8.0$ ) at $121^{\circ} \mathrm{C}$ for $90 \mathrm{~min}$ until no obvious color in the supernatant was observed. Supernatants were separated by centrifugation at $6000 \mathrm{~g}$ for $15 \mathrm{~min}$ to remove the soil particles and saved in a plastic tube $\left(4^{\circ} \mathrm{C}\right)$. Then $0.5 \mathrm{~mL}$ of supernatant of EE-GRSP and T-GRSP was stained with $5 \mathrm{~mL}$ of Coomassie Brilliant Blue G-250 and was read in a micro-plate reader 
140 (Biotek Synergy H4, Winooski, VT, USA) at $595 \mathrm{~nm}$. The bovine serum albumin was used as a 141 standard solution with Coomassie Brilliant Blue method and a standard curve was drawn to 142 determine the content of EE-GRSP and T-GRSP.

\section{AM fungal extra radical hyphal density and spore density}

146

147

We extracted fungal hyphae from soil according to the membrane filter method (Rillig, Field \& Allen, 1999). In total, $4.0 \mathrm{~g}$ of frozen soil from each sample was mixed with $12 \mathrm{~mL}$ sodium hexametaphosphate $\left(35 \mathrm{~g} \mathrm{~L}^{-1}\right)$ and $100 \mathrm{~mL}$ distilled deionized water in a flask, and then blended for $30 \mathrm{~s}$, settled for $30 \mathrm{~min}$ and sieved (38- $\mu \mathrm{m}$ sieve). The fungal hyphae on the sieve were washed into a flask with $200 \mathrm{~mL}$ distilled water, and then $2 \mathrm{~mL}$ aliquot was filtered through a $25-\mu \mathrm{m}$ Millipore filter. The fungal hyphae on the filter were stained with $1 \%$ acid fuchsine and distinguished into AM and non-AM fungi on the basis of morphological characteristics and staining color (Miller, Jastrow \& Reinhardt, 1995). We measured the hyphal length of AM fungi according to the grid-line intersect method (Tennant, 1975). We extracted AM fungal spores from $20 \mathrm{~g}$ air dried soil from each sample according to the wet-sieving and decanting method (Daniels \& Skipper, 1982) and counted the spore numbers under $40 \times$ magnification (Nikon 80i, Japan).

\section{DNA extraction, PCR and Illumina Miseq sequencing}

We extracted DNA from $0.2 \mathrm{~g}$ frozen roots and soil using the PowerSoil ${ }^{\circledR}$ DNA isolation kit (MOBIO Laboratories, Inc., Carlsbad, USA) in accordance with the manufacturer's instructions, and measured the DNA concentration using a NanoDrop 1000 Spectrophotometer (Thermo Scientific, Wilmington, USA). We amplified the fungal 18S rDNA region using a two-step PCR 
163 procedure. The first PCR using primers AML2 (Lee, Lee \& Young, 2008) and GeoA2 164 (Schwarzott \& Schüßler, 2001) was conducted in a final $25 \mu \mathrm{L}$ reaction mixture, including ca. 10 165 ng of template DNA, $0.75 \mu \mathrm{M}$ of each primer, $250 \mu \mathrm{M}$ of each dNTP, $0.5 \mathrm{U}$ KOD-plus-Neo 166 polymerase (Toyobo, Tokyo, Japan), $1.5 \mathrm{mM} \mathrm{MgSO}_{4}$, and $2.5 \mu \mathrm{L} 10 \times$ buffer. The thermal 167 cycling conditions were performed as follows: an initial denaturation at $95{ }^{\circ} \mathrm{C}$ for $5 \mathrm{~min}, 30$ 168 cycles for denaturation at $94{ }^{\circ} \mathrm{C}$ for $1 \mathrm{~min}$, annealing at $58{ }^{\circ} \mathrm{C}$ for $50 \mathrm{~s}$ and extension at $68^{\circ} \mathrm{C}$ for $1691 \mathrm{~min}$, and a final extension at $68^{\circ} \mathrm{C}$ for $10 \mathrm{~min}$. The products of the first amplification were 170 diluted 100 times, and $1 \mu \mathrm{L}$ of the diluted DNA template was used for the second amplification. 171 The thermal cycling conditions for the second amplification were the same as first amplification, 172 except that the primers NS31 (Simon, Lalonde \& Bruns, 1992) and AMDGR (Sato et al., 2005) 173 linked with 12-base barcode sequences were used. The size of amplified fragment was about 300 174 base pairs (bp). We purified the PCR products using a PCR Product Gel Purification Kit (Omega 175 Bio-Tek, USA), and pooled the purified PCR products with the same amount (100 ng) from each 176 sample and adjusted the concentration to $10 \mathrm{ng} \mu \mathrm{L}^{-1}$. We constructed a sequencing library by 177 addition of an Illumina sequencing $\quad$ adaptor $\quad$ 178 GATCGGAAGAGCACACGTCTGAACTCCAGTCACATCACGATCTCGTATGCCGTCTTC TGCTTG-3') to the products using the Illumina TruSeq DNA PCR-Free LT Library Prep Kit 180 (Illumina, CA, USA) according to the manufacturer's instructions. We sequenced the library by an Illumina MiSeq PE 250 platform using the paired-end $(2 \times 250$ bp $)$ option in the Chengdu 182 Institute of Biology, Chinese Academy of Sciences, China. 
v.1.7.0 (Caporaso et al., 2010) to eliminate low-quality sequences, such as read length $<200 \mathrm{bp}$,

187

no valid primer sequence or barcode sequence, containing ambiguous bases, or an average quality score $<20$. We checked and deleted the potential chimeras against the Maarj $A M$ database (Öpik et al., 2010) using the 'chimera.uchime' command in Mothur version 1.31.2 (Schloss et al., 2009). High quality sequences were subjected to de-replication and de-singleton, and then clustered into operational taxonomic units (OTUs) at a 97\% sequence similarity level using the cluster_otus command in USEARCH v8.0 (Edgar, 2013). Using a basic local alignment search tool (BLAST) (Altschul et al., 1990), we selected the most abundant sequence of each OTU and searched against the Maarj $A M$ database and National Center for Biotechnology Information (NCBI) nt database. We identified OTUs as the AM fungi based on the closest BLAST hit annotated as 'Glomeromycotina' and $E$ values $<\mathrm{e}^{-50}$. Furthermore, we normalized the sequence number of each sample to the smallest sample size using the 'sub.sample' command in Mothur. We have submitted the representative sequence of each AM fungal OTU to the European Molecular Biology Laboratory (EMBL) database (accession no. LR736402-LR736557). The identified AM fungi are shown in Supplementary Table S1.

\section{Statistical analysis}

We conducted all statistical analyses in R version 3.3.2 ( $R$ Development Core Team, 2017). Tukey's honestly significant difference (HSD) test or Conover's test was used to examine the significant difference of soil moisture, $\mathrm{pH}$, total $\mathrm{N}$, total $\mathrm{C}$ and total $\mathrm{P}$ in the grazing and nongrazing plots at $P<0.05$. Generalized linear model (GLM) with Poisson error structure and $\log$ link function was conducted to evaluate the effect of grazing on AM fungal spore density, extra 
208 radical hyphal density and T-GRSP, as these data did not meet normal distribution, while GLM

209 with Gaussian error structure and identity link function was conducted to evaluate the effect of 210 grazing on EE-GRSP, and then Conover's test was used to examine the significant difference

211 between grazing and non-grazing treatments at $P<0.05$ using the post-hoc.kruskal.conover.test

212 function in the PMCMR package (Pohlert, 2014). Meanwhile, GLM with Gaussian error 213 structure and identity link function was used to evaluate the effect of grazing and sample type 214 nested in grazing on the AM fungal OTU richness, and GLM with Gamma error structure and 215 inverse link function was used to evaluate the effect of grazing and sample type nested in grazing 216 on the relative abundance of abundant OTUs (relative abundance $>1 \%$ ) and orders of AM fungi, 217 as these data did not meet normal distribution, and then Conover's test was conducted for 218 comparisons between grazing and non-grazing treatments in soil and roots at $P<0.05$.

219 The distance matrices of AM fungal community composition (Hellinger-transformed OTU 220 read data) in roots and soil were established by the Bray-Curtis method (Clarke, Somerfield \& 221 Chapman, 2006). Nested permutational multivariate analysis of variance (PerMANOVA) was 222 conducted to examine the effect of grazing and sample type nested within grazing on AM fungal 223 community composition, using the 'adonis' function in the vegan with 999 permutations 224 (Oksanen et al., 2013). Besides, PerMANOVA was conducted to examine the effect of grazing 225 on AM fungal community composition in soil and roots, respectively. Redundancy analysis 226 (RDA) was conducted to reveal the significant correlation of AM fungal community composition 227 and soil variables using the Monte Carlo permutation test with 999 permutations.

\section{RESULTS}


231

232

233

234

235

236

237

238

239

240

241

242

243

244

245

246

247

248

249

250

251

252

253

\section{Soil properties}

Soil $\mathrm{pH}$ was significantly lower in grazing treatment than in non-grazing treatment (Table 1). Soil moisture, total $\mathrm{N}$, total $\mathrm{C}$ and total $\mathrm{P}$ were significantly higher in grazing treatment than in non-grazing treatment (Table 1).

\section{EE-GRSP and T-GRSP contents}

The EE-GRSP content was $28.96 \pm 3.73 \mu \mathrm{g} \mathrm{g} \mathrm{g}^{-1}($ mean $\pm \mathrm{SE})$ and $25.71 \pm 2.26 \mu \mathrm{g} \mathrm{g}^{-1}$ in grazing and non-grazing treatments, respectively. The T-GRSP content was $96.7 \pm 18.82 \mu \mathrm{g} \mathrm{g}^{-1}$ and $71.87 \pm 12.87 \mu \mathrm{g} \mathrm{g}^{-1}$ in grazing and non-grazing treatments, respectively. GLM showed that grazing significantly influenced EE-GRSP $(P=0.002$; Table 2$)$ and T-GRSP $(P<0.001$; Table 2). For example, EE-GRSP and T-GRSP contents were significantly lower in non-grazing than in grazing treatments (Fig. 1a and b).

\section{AM fungal spore density and extra radical hyphal density}

The spore density of AM fungi was $25.89 \pm 12.17 \mathrm{~g}^{-1}\left(\right.$ mean $\pm \mathrm{SE}$ ) and $15.03 \pm 5.88 \mathrm{~g}^{-1}$ in grazing and non-grazing treatments, respectively. The extra radical hyphal density of AM fungi was $4.00 \pm 2.51 \mathrm{~m} \mathrm{~g}^{-1}$ and $3.10 \pm 1.56 \mathrm{~m} \mathrm{~g}^{-1}$ in grazing and non-grazing treatments, respectively. GLM revealed that grazing significantly affected AM fungal spore density $(P=0.001$; Table 2$)$ but not extra radical hyphal density $(P=0.130$; Table 2$)$. For example, the spore density of AM fungi was significantly lower in non-grazing than in grazing treatments (Fig. 1c). However, AM fungal extra radical hyphal density was not significantly different in non-grazing and grazing treatments (Fig. 1d). 
254

255

256

257

258

259

260

261

262

263

264

265

266

267

268

269

270

271

272

273

274

275

276

\section{Identification of AM fungi}

In total, 3,205,557 high-quality sequences were filtered from 3,335,816 raw sequences and clustered into 882 OTUs at a 97\% sequence similarity level. Among 882 OTUs, 156 (2,919,706 sequences) belonged to AM fungi. As the sequence number of AM fungi varied from 20,408 to 48,572 in the 80 samples, the number of sequence was normalized to 20,408 . The normalized dataset contained 156 AM fungal OTUs (1,632,640 sequences). Of the 156 AM fungal OTUs obtained, 154 were from soil, 152 from roots, and 150 shared both soil and roots. Among 156 AM fungal OTUs, 153 were detected from more than three samples (frequency $\geq 3.75 \%$ ) (Supplementary Fig. S2a). Furthermore, the 21 abundant AM fungal OTUs (relative abundance > $1 \%$ ) occupied $83.85 \%$ of the total sequences (Supplementary Fig. S2b). Among 156 AM fungal OTUs, 109 were identified to Glomerales (79.52\% of sequences), 22 to Diversisporales (10.84\%), 21 to Archaeosporales $(8.75 \%)$, and 4 to Paraglomerales $(0.89 \%)$. In addition, the rarefaction curves indicated that the sample numbers were sufficient to detect the most AM fungi in this study (Supplementary Fig. S3).

\section{AM fungal OTU richness}

AM fungal OTU richness in grazing and non-grazing treatments was $123.70 \pm 2.96$ (mean \pm $\mathrm{SE})$ and $122.85 \pm 3.01$ in soil, and $117.55 \pm 2.26$ and $118.00 \pm 4.38$ in roots, respectively. GLM revealed that AM fungal OTU richness was influenced by sample type (root and soil; $P<0.001$; Supplementary Table S2), but not by grazing $(P=0$. 662; Supplementary Table S2). For example, AM fungal OTU richness was significantly lower in roots than in soil in both grazing and non-grazing treatments (Fig. 2). However, AM fungal OTU richness was not significantly different between grazing and non-grazing treatments in roots and soil, respectively (Fig. 2). 
278 AM fungal community

GLM revealed that grazing had significant effect on the relative abundance of abundant

280

281

282

283

284

285

286

287

288

289

290

291

292

293

294

295

296

297

298

299

AM fungal OTU12 and OTU25 (Glomerales), and sample type had significant effect on the relative abundance of abundant AM fungal OTU4, OTU5, OTU7, OTU12, OTU14, OTU18, OTU25 and OTU141 (Glomerales), OTU8 and OTU17 (Diversisporales) and OTU23 (Archaeosporales) (Fig. 3; Supplementary Table S3; Supplementary Table S4).

GLM revealed that sample type significantly influenced the relative abundance of Glomerales, Diversisporales and Archaeosporales, and grazing significantly affected the relative abundance of Diversisporales (Fig. 4; Supplementary Table S5). The relative abundance of Glomerales was significantly lower in soil than in roots; by contrast, the relative abundance of Diversisporales and Archaeosporales was significantly lower in roots than in soil, regardless of non-grazing and grazing treatments (Fig. 4; Supplementary Table S5). Besides, the relative abundance of Diversisporales was significantly lower in grazing treatment than in non-grazing treatment (Fig. 4; Supplementary Table S5).

The PerMANOVA demonstrated that the community composition of AM fungi was significantly influenced by sample type (soil and root; $F=7.2836, R^{2}=0.157, P=0.001$; Supplementary Table S6) and grazing $\left(F=2.339, R^{2}=0.025, P=0.012\right.$; Supplementary Table S6). Furthermore, the community composition of AM fungi was significantly influenced by grazing in soil $\left(F=2.639, R^{2}=0.055, P=0.001\right.$; Supplementary Table $\left.\mathrm{S} 7\right)$, but not in roots $(F=$ 0.998, $R^{2}=0.025, P=0.419$; Supplementary Table S8). Furthermore, RDA showed that the community composition of AM fungi in soil and roots was significantly correlated with soil $\mathrm{pH}$, moisture, total C, total $\mathrm{N}$ and total P (Fig. 5). 


\section{DISCUSSION}

302

303

304

305

306

307

308

309

310

311

312

313

314

al., 2009; Martínez-García et al., 2011). However, we found that grazing did not significantly

influence AM fungal richness in roots and soil. Similarly, a previous study showed that moderate grazing could maintain the AM fungal diversity (Dudinszky et al., 2019). In general, AM fungi 
323 have low specificity (Smith \& Read, 2008), thus AM fungal richness may not be influenced by

324 the low plant species diversity caused by moderate grazing, as some studies found that AM

325 fungal richness was not related to plant species diversity (Wolf et al., 2003).

326 The community composition of AM fungi significantly differed between roots and soil in 327 this study, as previous studies reported in grassland (Yang et al., 2013), farmland (Liu et al., 328 2016) and temperate (Saks et al., 2014) and subtropical forest (Maitra et al., 2019) ecosystems.

329 This may be explained by the difference in AM fungal abundance in roots and soil (Hempel, 330 Renker \& Buscot, 2007; Maitra et al., 2019). Indeed, our result found that some AM fungi were 331 abundant in roots and soil, respectively. In addition, AM fungal phenology may produce 332 different communities in soil and roots (Liu et al., 2012).

333 Grazing significantly affected the AM fungal community composition in soil, in consistent 334 with some previous studies reported in desert steppe and grassland ecosystems (Murray, Frank 335 \& Gehring, 2010; Bai et al., 2013). Grazing may influence the AM fungal community 336 composition by changing soil properties through animal trampling and fecal deposition 337 (McNaughton, Banyikwa \& McNaughton, 1997; Yang et al., 2019). For example, animal 338 trampling may make the soil tight and alter soil bulk density (Kauffman, Thorpe \& Brookshire, 339 2004; Byrnes et al., 2018), thereby influencing AM fungal community (Yang et al., 2018). Moreover, dung and urine produced by animals, as soil fertilization, may decrease soil $\mathrm{pH}$ and 341 increase soil nutrients as shown in this and previous studies (McNaughton, Banyikwa \& McNaughton, 1997; Kohler et al., 2005), thus altering AM fungal community composition. Indeed, our result showed that the community composition of AM fungi was significantly related to soil $\mathrm{pH}$, moisture, total $\mathrm{C}$, total $\mathrm{N}$ and total $\mathrm{P}$, as previous studies reported in semi-arid, alpine 345 and temperate grassland and subtropical forest ecosystems (Zheng et al., 2014; Gao et al., 2016; 
346 Zhang et al., 2016; Goldmann et al., 2019; Maitra et al., 2019). However, the AM fungal

347 community composition in roots was not significantly influenced by grazing, as previous studies

348 reported in semi-arid and alpine grassland ecosystems (González et al., 2018; Jiang et al., 2018).

349 It is possible that moderate grazing does not much change the allocation of carbohydrates to

350 roots, thereby without altering AM fungal community. Furthermore, although grazing may alter

351 the AM fungal function, it does not necessarily alter the community in roots (González et al.,

352 2018).

353

354

CONCLUSIONS

In conclusion, we examined the AM fungi in response to grazing in the Zoige wetland on

356

357

358

359

360

361

362

363

364

365

366

367

368

the Qinghai-Tibet plateau for the first time. AM fungal spore density and GRSP content positively responded to grazing. The extra radical hyphal density and OTU richness of AM fungi had neutral response to grazing. The community composition of AM fungi was significantly influenced by grazing in soil but not in roots. These findings suggest that moderate grazing can increase the biomass of AM fungi and soil $\mathrm{C}$ sequestration, and maintain the AM fungal diversity in the wetland ecosystem on the Qinghai-Tibet Plateau. Future studies can focus on measuring C flux between AM fungi and host to fully understand the role of grazing on AM fungal function in wetland ecosystems.

\section{ACKNOWLEDGEMENTS}

We thank Ga E, Ying Ban and Hongjun Wang from Zoige Wetland National Nature Reserve Authority for help during sampling. 


\section{Funding}

370 This study was supported financially by the National Natural Science Foundation of China (no. $37191751113)$.

\section{REFERENCES}

Altschul SF, Gish W, Miller W, Myers EW, Lipman DJ. 1990. Basic local alignment search tool. Journal of Molecular Biology 215: 403-410 DOI: 10.1016/S0022-2836(05)80360-2.

Ba L, Ning JX, Wang DL, Facelli E, Facelli JM, Yang YN, Zhang LC. 2012. The relationship between the diversity of arbuscular mycorrhizal fungi and grazing in a meadow steppe. Plant and Soil 352: 143-156 DOI: 10.1007/s11104-011-0985-6.

Bai G, Bao YY, Du GX, Qi YL. 2013. Arbuscular mycorrhizal fungi associated with vegetation and soil parameters under rest grazing management in a desert steppe ecosystem. Mycorrhiza 23: 289-301 DOI: 10.1007/s00572-012-0468-5.

Bennett AE, Bever JD. 2007. Mycorrhizal species differentially alter plant growth and response to herbivory. Ecology 88: 210-218 DOI: 10.1890/0012-9658(2007)88[210: MSDAPG]2.0.CO;2.

Byrnes RC, Eastburn DJ, Tate KW, Roche LM. 2018. A global meta-analysis of grazing impacts on soil health indicators. Journal of Environmental Quality 47: 758-765 DOI: 10.2134/jeq2017.08.0313.

Caporaso JG, Kuczynski J, Stombaugh J, Bittinger K, Bushman FD, Costello EK, Fierer N, Pena AG, Goodrich JK, Gordon JI, Huttley GA, Kelley ST, Knight D, Koening JE, Ley RE, Lozupone CA, McDonald D, Muegge BD, Pirrung M, Reeder J, Sevinsky JR, Tumbaugh PJ, Walters WA, Widmann J, Yatsunenko T, Zaneveld J, Knight R. 2010. QIIME allows 
392

393

394

395

396

397

398

399

400

401

402

403

404

405

406

407

408

409

410

411

412

413

414

analysis of high-throughput community sequencing data. Nature Methods 7: 335-336 DOI: 10.1038/nmeth.f.303.

Clarke KR, Somerfield PJ, Chapman MG. 2006. On resemblance measures for ecological studies, including taxonomic dissimilarities and a zero-adjusted Bray-Curtis coefficient for denuded assemblages. Journal of Experiment Marine Biology and Ecology 330: 55-80 DOI: 10.1016/j.jembe.2005.12.017.

Daniels B, Skipper H. 1982. Methods for the recovery and quantitative estimation of propagules from Soil. In: Schenck, N. (Ed.), Methods and Principles of Mycorrhizal Research, vol. 29. American Phytopathological Society, Minn, pp. 29-35.

Driver JD, Holben WE, Rillig MC. 2005. Characterization of glomalin as a hyphal wall component of arbuscular mycorrhizal fungi. Soil Biology and Biochemistry 37: 101-106 DOI: 10.1016/j.soilbio.2004.06.011.

Dudinszky N, Cabello MN, Grimoldi AA, Schalamuk S, Golluscio RA. 2019. Role of grazing intensity on shaping arbuscular mycorrhizal fungi communities in Patagonian semiarid steppes. Rangeland Ecology \& Management 72: 692-699 DOI: 10.1016/j.rama.2019.02.007.

Edgar RC. 2013. UPARSE: highly accurate OTU sequences from microbial amplicon reads. Nature Methods 10: 996-998 DOI: 10.1038/nmeth.2604.

Eom AH, Wilson GW, Hartnett DC. 2001. Effects of ungulate grazers on arbuscular mycorrhizal symbiosis and fungal community structure in tallgrass prairie. Mycologia 93: 233-242 DOI: 10.1080/00275514.2001.12063153.

Frolking S, Talbot J, Jones MC, Treat CC, Kauffman JB, Tuittila ES, Roulet N. 2011. Peatlands in the Earth's 21st century climate system. Environmental Reviews 19: 371-396 DOI: 
416 Gao C, Kim YC, Zheng Y, Yang W, Cheng L, Ji NN, Wan SQ, Guo LD. 2016. Increased

417

418

419

420

421

422

423

424

425

426

427

428

429

430

431

432

433

434

435

436

437 precipitation, rather than warming, exerts a strong influence on arbuscular mycorrhizal fungal community in a semiarid steppe ecosystem. Botany 94: 459-469 DOI: 10.1139/cjb2015-0210.

Gao YH, Luo P, Wu N, Chen H, Wang GX. 2007. Grazing intensity impacts on carbon sequestration in an alpine meadow on the eastern Tibetan Plateau. Research Journal of Agriculture and Biological Sciences 3: 642-647.

García I, Mendoza R. 2012. Impact of defoliation intensities on plant biomass, nutrient uptake and arbuscular mycorrhizal symbiosis in Lotus tenuis growing in a saline-sodic soil. Plant Biology 14: 964-971 DOI: 10.1111/j.1438-8677.2012.00581.x.

Godbold DL, Hoosbeek MR, Lukac M, Cotrufo MF, Janssens LA, Ceulemans R, Polle A, Velthorst EJ, Scarascia-Mugnozza G, Angelis P, Miglietta F, Peressotti A. 2006. Mycorrhizal hyphal turnover as a dominant process for carbon into soil organic matter. Plant and Soil 281: 15-24 DOI: 10.1007/s11104-005-3701-6.

Goldmann K, Boeddinghaus RS, Klemmer S, Regan KM, Heintz-Buschart A, Fischer M, Prati D, Piepho HP, Berner D, Marhan S, Kandeler E, Buscot F, Wubet E. 2019. Unraveling spatiotemporal variability of arbuscular mycorrhiza fungi in a temperate grassland plot. Environmental Microbiology DOI: 10.1111/1462-2920.14653.

González JB, Petipas RH, Franken O, Kiers ET, Veblen KE, Brody AK. 2018. Herbivore removal reduces influence of arbuscular mycorrhizal fungi on plant growth and tolerance in an east African savanna. Oecologia 187: 123-133 DOI: 10.1007/s00442-018-4124-4.

Green AJ, Alcorlo P, Peeters ET, Morris EP, Espinar JL, Bravo-Utrera M A, Bustamante J, Díaz- 
438

439

440

441

442

443

444

Delgado R, Koelmans AA, Mateo R, Mooij WM, Rodríguez-Rodríguez M, van Nes EH, Scheffer M. 2017. Creating a safe operating space for wetlands in a changing climate. Frontiers in Ecology and the Environment 15, 99-107 DOI: 10.1002/fee.1459.

Guo XJ, Du W, Wang X, Yang ZF. 2013. Degradation and structure change of humic acids corresponding to water decline in Zoige peatland, Qinghai-Tibet Plateau. Science of the Total Environment 445: 231-236 DOI: 10.1016/j.scitotenv.2012.12.048.

Hammer EC, Rillig MC. 2011. The influence of different stresses on glomalin levels in an arbuscular mycorrhizal fungus-salinity increases glomalin content. PLoS ONE 6: e28426. DOI: 10.1371/journal.pone.0028426.

Hempel S, Renker C, Buscot F. 2007. Differences in the species composition of arbuscular mycorrhizal fungi in spore, root and soil communities in a grassland ecosystem. Environmental Microbiology 9: 1930-1938 DOI: 10.1111/j.1462-2920.2007.01309.x.

Hoffmann C, Giese M, Dickhoefer U, Wan HW, Bai YF, Steffens M, Liu CY, Butterbach-Bahl K, Han XG. 2016. Effects of grazing and climate variability on grassland ecosystem functions in Inner Mongolia: synthesis of a 6-year grazing experiment. Journal of Arid Environments 135: 50-63 DOI: 10.1016/j.jaridenv.2016.08.003.

Janos DP, Garamszegi S, Beltran B. 2008. Glomalin extraction and measurement. Soil Biology and Biochemistry 40: 728-739 DOI: 10.1016/j.soilbio.2007.10.007.

Jiang SJ, Pan JB, Shi GX, Dorji T, Hopping KA, Klein JA, Liu YJ, Feng HY. 2018. Identification of root-colonizing AM fungal communities and their responses to short-term climate change and grazing on Tibetan plateau. Symbiosis 74: 159-166 DOI: 10.1007/s13199-017-0497-0.

Junk WJ, An SQ, Finlayson CM, Gopal B, Květ J, Mitchell SA, Mitsch WJ, Robarts R D. 2013. 
461

462

463

464

465

466

467

468

469

470

471

472

473

474

475

476

477

478

479

480

481

482

483

Current state of knowledge regarding the world's wetlands and their future under global climate change: a synthesis. Aquatic Sciences 75: 151-167 DOI: 10.1007/s00027-0120278-Z.

Kauffman JB, Thorpe AS, Brookshire ENJ. 2004. Livestock exclusion and belowground ecosystem responses in riparian meadows of eastern Oregon. Ecological Applications 14: 1671-1679 DOI: 10.1890/03-5083.

Kohler F, Hamelin J, Gillet F, Gobat JM, Buttler A. 2005. Soil microbial community changes in wooded mountain pastures due to simulated effects of cattle grazing. Plant and Soil 278: 327-340 DOI: 10.1007/s11104-005-8809-1.

Kusakabe R, Taniguchi T, Goomaral A, Undarmaa J, Yamanaka N, Yamato M. 2018. Arbuscular mycorrhizal fungal communities under gradients of grazing in Mongolian grasslands of different aridity. Mycorrhiza 28: 621-634. DOI: 10.1007/s00572-018-0855-7.

Lee J, Lee S, Young JPW. 2008. Improved PCR primers for the detection and identification of arbuscular mycorrhizal fungi. FEMS Microbiology Ecology 65: 339-349 DOI: 10.1111/j.1574-6941.2008.00531.x.

Liu W, Zhang YL, Jiang SS, Deng Y, Christie P, Murray PJ, Li XL, Zhang JL. 2016. Arbuscular mycorrhizal fungi in soil and roots respond differently to phosphorus inputs in an intensively managed calcareous agricultural soil. Scientific Reports 6: 24902 DOI: $10.1038 /$ srep24902.

Liu YJ, He L, An LZ, Helgason T, Feng HY. 2009. Arbuscular mycorrhizal dynamics in a chronosequence of Caragana korshinskii plantations. FEMS Microbiology Ecology 67: 81-92 DOI: 10.1111/j.1574-6941.2008.00597.x.

Liu YJ, Shi GX, Mao L, Cheng G, Jiang SJ, Ma XJ, An LZ, Du ZG, Johnson NC, Feng H. 2012. 
484

485

486

487

488

489

490

491

492

493

494

495

496

497

498

499

500

501

502

503

504

505

506

Direct and indirect influences of $8 \mathrm{yr}$ of nitrogen and phosphorus fertilization on Glomeromycota in an alpine meadow ecosystem. New Phytologist 194: 523-535 DOI: 10.1111/j.1469-8137.2012.04050.x.

Maitra P, Zheng Y, Chen L, Wang YL, Ji NN, Lü PP, Gan HY, Li XC, Sun X, Zhou XH, Guo LD. 2019. Effect of drought and season on arbuscular mycorrhizal fungi in a subtropical secondary forest. Fungal Ecology 41: 107-115 DOI: 10.1016/j.funeco.2019.04.005.

Martínez-García LB, Armas C, de Dios Miranda J, Padilla FM, Pugnaire FI. 2011. Shrubs influence arbuscular mycorrhizal fungi communities in a semi-arid environment. Soil Biology and Biochemistry 43: 682-689 DOI: 10.1016/j.soilbio.2010.12.006.

McNaughton SJ, Banyikwa FF, McNaughton MM. 1997. Promotion of the cycling of dietenhancing nutrients by African grazers. Science 278: 1798-1800 DOI: 10.1126/science. 278.5344 .1798 .

Miller RM, Jastrow JD, Reinhardt DR. 1995. External hyphal production of vesicular-arbuscular mycorrhizal fungi in pasture and tallgrass prairie communities. Oecologia 103: 17-23 DOI: 10.1007/BF00328420.

Murray TR, Frank DA, Gehring CA. 2010. Ungulate and topographic control of arbuscular mycorrhizal fungal spore community composition in a temperate grassland. Ecology 91: 815-827 DOI: 10.1890/09-0209.1.

Oksanen J, Blanchet FG, Kindt R, Legendre P, Minchin PR, O'Hara RB, Simpson GL, Solymos P, Stevens MHH, Wagner H. 2013. Vegan: community ecology package. R package version 2.0-7 Available at http://CRAN.R-project.org/package=vegan.

Öpik M, Vanatoa A, Vanatoa E, Moora M, Davison J, Kalwij JM, Reier Ü, Zobel M. 2010. The online database Maarj $A M$ reveals global and ecosystemic distribution patterns in arbuscular 
507

508

509

510

511

512

513

514

515

516

517

518

519

520

521

522

523

524

525

526

527

528

529

mycorrhizal fungi (Glomeromycota). New Phytologist 188: 223-241 DOI: 10.1111/j.14698137.2010.03334.x.

Pohlert T. 2014. The pairwise multiple comparison of mean ranks package (PMCMR). R package version 4.1. Available at http://cran.r-project.org/package $=P M C M R$.

R Development Core Team. 2017. R: A language and environment for statistical computing. Vienna, Austria: R Foundation for Statistical Computing. Available at: http://www.Rproject.org.

Ren HY, Gui WY, Bai YF, Stein C, Rodrigues JLM, Wilson GWT, Cobb AB, Zhang YJ, Yang GW. 2018. Long-term effects of grazing and topography on extra-radical hyphae of arbuscular mycorrhizal fungi in semi-arid grasslands. Mycorrhiza 28: 117-127 DOI: 10.1007/s00572-017-0812-x.

Rillig MC, Field CB, Allen MF. 1999. Soil biota responses to long-term atmospheric $\mathrm{CO}_{2}$ enrichment in two California annual grasslands. Oecologia 119: 572-577 DOI: $10.1007 / \mathrm{s} 004420050821$.

Saks Ü, Davison J, Öpik M, Vasar M, Moora M, Zobel M. 2014. Root-colonizing and soil-born communities of arbuscular mycorrhizal fungi in a temperate forest understory. Botany 92 : 277-285 DOI: 10.1139/cjb-2013-0058.

Sato K, Suyama Y, Saito M, Sugawara K. 2005. A new primer for discrimination of arbuscular mycorrhizal fungi with polymerase chain reaction-denature gradient gel electrophoresis. Grassland Science 51: 179-181 DOI: 10.1111/j.1744-697X.2005.00023.x.

Schloss PD, Westcott SL, Ryabin T, Hall JR, Hartmann M, Hollister EB, Lesniewski RA, Oakley BB, Parks DH, Robinson CJ, Sahl JW, Stres B, Thallinger GG, Van Horn DJ, Weber CF. 2009. Introducing mothur: open-source, platform-independent, community- 
530

531

532

533

534

535

536

537

538

539

540

541

542

543

544

545

546

547

548

549

550

551

552

supported software for describing and comparing microbial communities. Applied and Environmental Microbiology 75: 7537-7541 DOI: 10.1128/AEM.01541-09.

Schwarzott D, Schüßler A. 2001. A simple and reliable method for SSU rRNA gene DNA extraction, amplification, and cloning from single AM fungal spores. Mycorrhiza 10: 203-207 DOI: 10.1007/PL00009996.

Simon L, Lalonde M, Bruns TD. 1992. Specific amplification of 18S fungal ribosomal genes from vesicular-arbuscular endomycorrhizal fungi colonizing roots. Applied and Environmental Microbiology 58: $291-295$ Available

at https://aem.asm.org/content/58/1/291.

Smith SE, Read DJ. 2008. Mycorrhizal Symbiosis, third ed. Academic Press, New York; USA.

Soka GE, Ritchie ME. 2018. Arbuscular mycorrhizal spore composition and diversity associated with different land uses in a tropical savanna landscape, Tanzania. Applied Soil Ecology 125: 222-232 DOI: 10.1016/j.apsoil.2018.01.013.

Su YY, Guo LD. 2007. Arbuscular mycorrhizal fungi in non-grazed, restored and over-grazed grassland in the Inner Mongolia steppe. Mycorrhiza 17: 689-693 DOI: 10.1007/s00572007-0151-4.

Tennant D. 1975. A test of a modified line intersect method of estimating root length. Journal of Ecology 995-1001 DOI: 10.2307/2258617.

van der Heijden MGA, Bardgett RD, van Straalen NM. 2008. The unseen majority: soil microbes as drivers of plant diversity and productivity in terrestrial ecosystems. Ecology Letters 11: 296-310 DOI: 10.1111/j.1461-0248.2007. 01139.x.

van der Heyde M, Abbott LK, Gehring C, Kokkoris V, Hart MM. 2019. Reconciling disparate responses to grazing in the arbuscular mycorrhizal symbiosis. Rhizosphere 11: 100167 DOI: 
553

554

555

556

557

558

559

560

561

562

563

564

565

566

567

568

569

570

571

572

573

574

575

10.1016/j.rhisph.2019.100167.

van der Heyde M, Bennett JA, Pither J, Hart M. 2017. Longterm effects of grazing on arbuscular mycorrhizal fungi. Agriculture, Ecosystems \& Environment 243: 27-33 DOI: 10.1016/j.agee.2017.04.003.

Wang Q, Bao WK, Yan ZL. 2002. Basic types and characters of the western Zoige meadows and their changes in recent decades. Chinese Journal of Applied and Environmental Biology 8: 133-141 (in Chinese).

Wolf J, Johnson NC, Rowland DL, Reich PB. 2003. Elevated $\mathrm{CO}_{2}$ and plant species richness impact arbuscular mycorrhizal fungal spore communities. New Phytologist 157: 579-588 DOI: 10.1046/j.1469-8137.2003.00696.x.

Xiang S, Guo RQ, Wu N, Sun SC. 2009. Current status and future prospects of Zoige marsh in eastern Qinghai-Tibet plateau. Ecological Engineering 35, 553-562 DOI: 10.1016/j.ecoleng.2008.02.016.

Yan CG, Zhang MX. 2005. Wetland vegetation in China and its conservation advices. Wetland Science 03: 210-215 (in Chinese).

Yang F, Niu KC, Collins CG, Yan XB, Ji YG, Ling N, Zhou XH, Du GZ, Guo H, Hu SJ. 2019. Grazing practices affect the soil microbial community composition in a Tibetan alpine meadow. Land Degradation \& Development 30: 49-59 DOI: 10.1002/1dr.3189.

Yang W, Gu SY, Xin Y, Bello A, Sun WP, Xu XH. 2018. Compost addition enhanced hyphal growth and sporulation of arbuscular mycorrhizal fungi without affecting their community composition in the soil. Frontiers in Microbiology 9: 169 DOI: 10.3389/fmicb.2018.00169.

Yang W, Zheng Y, Gao C, He XH, Ding Q, Kim YC, Rui YC, Wang SP, Guo LD. 2013. The arbuscular mycorrhizal fungal community response to warming and grazing differs between 
576 soil and roots on the Qinghai-Tibetan plateau. PLoS ONE 8: e76447 DOI:

577 10.1371/journal.pone.0076447.

578 Zhang J, Wang F, Che RX, Wang P, Liu HK, Ji BM, Cui XY. 2016. Precipitation shapes

579 communities of arbuscular mycorrhizal fungi in Tibetan alpine steppe. Scientific Reports 6:

$580 \quad 23488$ DOI: $10.1038 / \operatorname{srep} 23488$.

581 Zheng Y, Kim YC, Tian XF, Chen L, Yang W, Gao C, Song MH, Xu XL, Guo LD. 2014.

582 Differential responses of arbuscular mycorrhizal fungi to nitrogen addition in a near pristine

583 Tibetan alpine meadow. FEMS Microbiology Ecology 89: 594-605 DOI: 10.1111/1574-

$584 \quad 6941.12361$.

585 Zhou GY, Zhou XH, He YH, Shao JJ, Hu ZH, Liu RQ, Zhou HM, Hosseinibai S. 2017. Grazing

586 intensity significantly affects belowground carbon and nitrogen cycling in grassland

587 ecosystems: a meta-analysis. Global Change Biology 23: 1167-1179 DOI:

$588 \quad 10.1111 / \mathrm{gcb} .13431$. 
589

590

591

592

593

594

595

596

597

598

599

600

601

602

603

604

605

606

607

608

609

610

611

\section{Figure legend}

Fig. 1. Easily extracted glomalin-related soil protein (EE-GRSP, a), total extracted GRSP (TGRSP, b), spore density (c) and extra radical hyphal (ERH) density (d) of arbuscular mycorrhizal (AM) fungi in grazing and non-grazing treatments. Data are means \pm SE $(n=20)$. Bars with different letters denote significant difference in grazing and non-grazing treatments according to Conover's HSD test at $P<0.05$.

Fig. 2. The operational taxonomic unit (OTU) richness of arbuscular mycorrhizal (AM) fungi in soil and roots in grazing and non-grazing treatments. General linear model (GLM) showing the effect of grazing and sample type (soil and root) on the OTU richness. Data are means \pm SE $(n=$ 20). Bars with different letters denote significant difference in grazing and non-grazing treatments according to Conover's test at $P<0.05$. G, grazing; NG, non-grazing; ST, sample type.

Fig. 3. Relative abundance of arbuscular mycorrhizal (AM) fungal operational taxonomic units (OTUs) in soil and roots in grazing and non-grazing treatments. General linear models (GLMs) showing the effect of grazing and sample type (soil and root) on the relative abundance of AM fungal OTUs (ns; $P \geq 0.05, * P<0.05, * * P<0.01$, *** $P<0.001$ ). The rare AM fungal OTUs ( $<1 \%$ of total AM fungal reads) and abundant AM fungal OTUs ( $>1 \%$ of total AM fungal reads) that was not significantly affected by grazing and sample type were all assigned to "Others". SN, soil non-grazing; SG, soil grazing; RN, root non-grazing; RG, root grazing; G, grazing; NG, nongrazing; ST, sample type. 
613 Fig. 4. Relative abundance of arbuscular mycorrhizal (AM) fungi at the order level in soil and 614 roots in grazing and non-grazing treatments. General linear model (GLM) showing the effect of 615 grazing and sample type (soil and root) on the relative abundance of AM fungal orders (ns; $P \geq$ $6160.05, * * * P<0.001)$. Different letters are significantly different at $P<0.05$, as indicated by 617 Conover's test. SN, soil non-grazing; SG, soil grazing; RN, root non-grazing; RG, root grazing; 618 G, grazing; NG, non-grazing; ST, sample type.

619

620 Fig. 5. Redundancy analysis (RDA) biplots showing arbuscular mycorrhizal fungal community 621 composition in soil and roots (a), soil (b) and roots (c). Significant soil variables were presented 622 as vectors on the RDA biplot graphs using the 'envfit' (based on 999 permutations) at $P<0.05$. $623 \mathrm{SN}$, soil non-grazing; SG, soil grazing; RN, root non-grazing; RG, root grazing; N, soil total 624 nitrogen; C, soil total carbon; $\mathrm{P}$, soil total phosphorus. 


\section{Figure 1}

Easily extracted glomalin-related soil protein, total extracted GRSP, spore density and extra radical hyphal density of arbuscular mycorrhizal fungi in grazing and non-grazing treatments.

Fig. 1. Easily extracted glomalin-related soil protein (EE-GRSP, a), total extracted GRSP (TGRSP, b), spore density (c) and extra radical hyphal (ERH) density (d) of arbuscular mycorrhizal (AM) fungi in grazing and non-grazing treatments. Data are means $\pm S E$ ( $n=$ 20). Bars with different letters denote significant difference in grazing and non-grazing treatments according to Conover's test at $P<0.05$. 

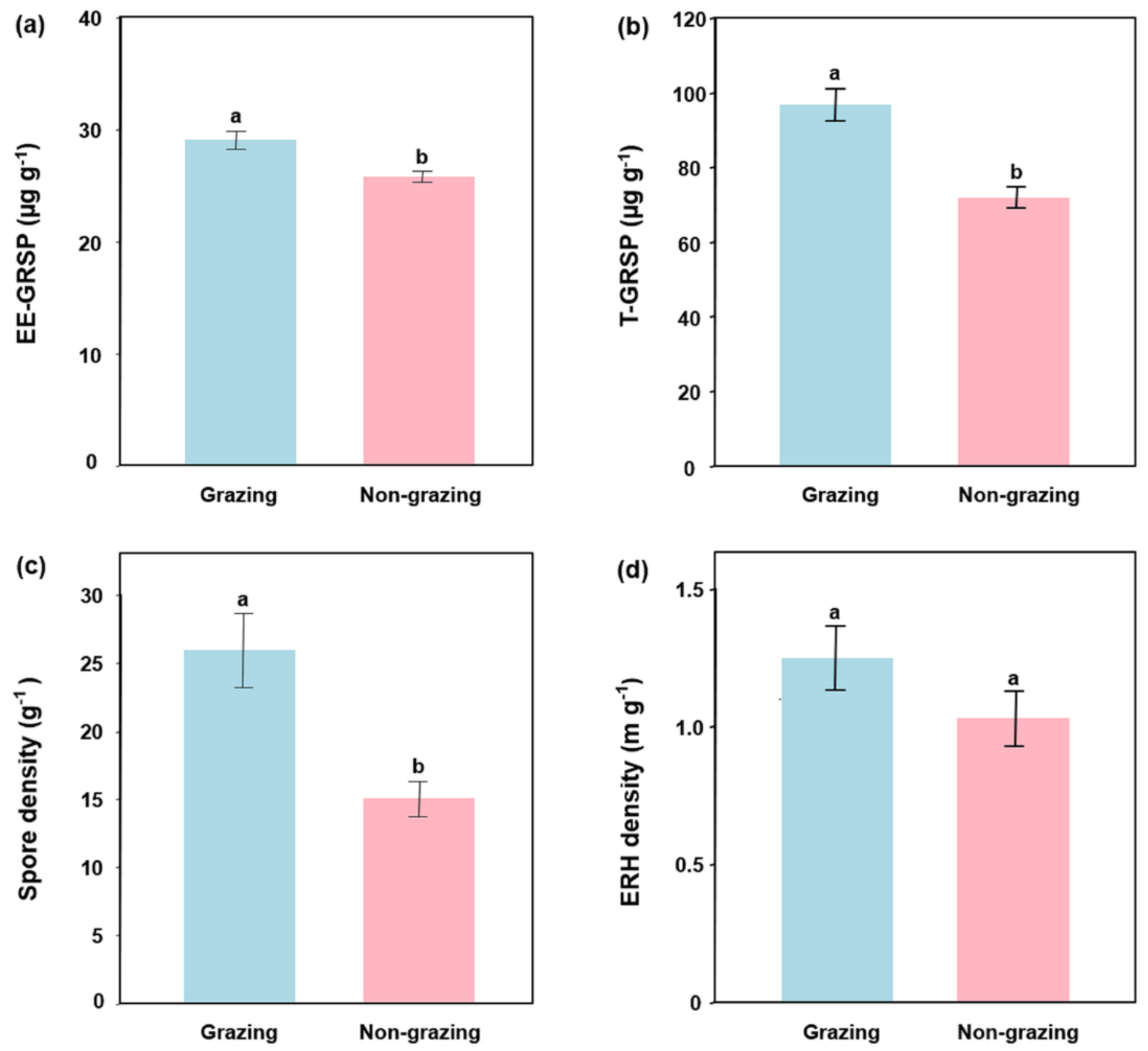


\section{Figure 2}

Grazing did not significantly affected AM fungal richness.

Fig. 2. The operational taxonomic unit (OTU) richness of arbuscular mycorrhizal (AM) fungi in soil and roots in grazing and non-grazing treatments. General linear model (GLM) showing the effect of grazing and sample type (soil and root) on the OTU richness. Data are means \pm SE $(n=20)$. Bars with different letters denote significant difference in grazing and nongrazing treatments according to Conover's test at $P<0.05 . \mathrm{G}$, grazing; NG, non-grazing; ST, sample type.

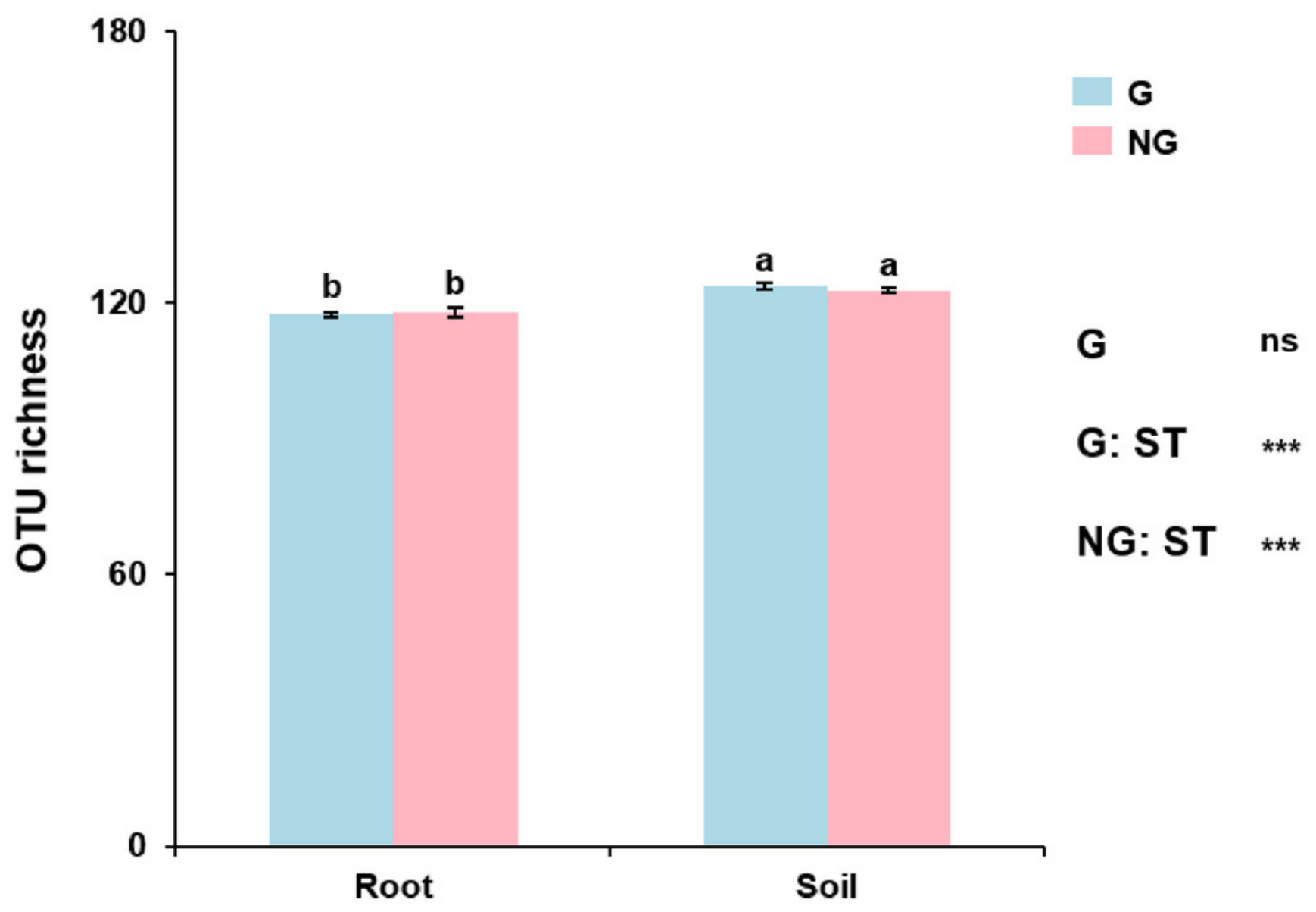




\section{Figure 3}

Relative abundance of arbuscular mycorrhizal (AM) fungal operational taxonomic units (OTUs) in soil and roots in grazing and non-grazing treatments.

Fig. 3. Relative abundance of arbuscular mycorrhizal (AM) fungal operational taxonomic units (OTUs) in soil and roots in grazing and non-grazing treatments. General linear models (GLMs) showing the effect of grazing and sample type (soil and root) on the relative abundance of AM fungal OTUs (ns; $P \geq 0.05, * P<0.05$, ** $P<0.01$, *** $P<0.001$ ). The rare AM fungal OTUs ( $<1 \%$ of total AM fungal reads) and abundant AM fungal OTUs ( $>1 \%$ of total AM fungal reads) that was not significantly affected by grazing and sample type were all assigned to "Others". SN, soil non-grazing; SG, soil grazing; RN, root non-grazing; RG, root grazing; G, grazing; NG, non-grazing; ST, sample type.

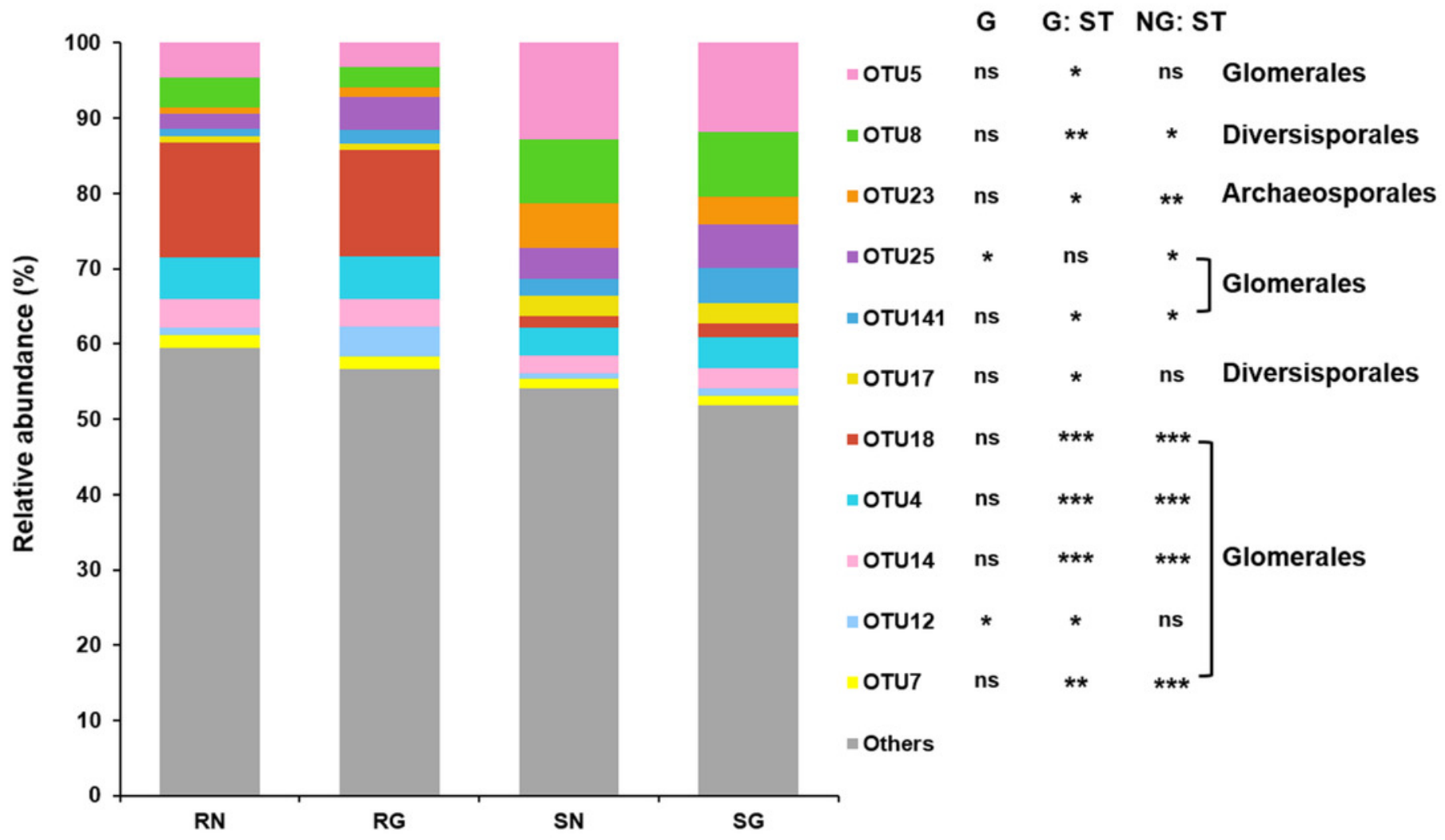




\section{Figure 4}

Relative abundance of arbuscular mycorrhizal (AM) fungi at the order level in soil and roots in grazing and non-grazing treatments.

Fig. 4. Relative abundance of arbuscular mycorrhizal (AM) fungi at the order level in soil and roots in grazing and non-grazing treatments. General linear model (GLM) showing the effect of grazing and sample type (soil and root) on the relative abundance of AM fungal orders (ns; $P \geq 0.05, * * * P<0.001$ ). Different letters are significantly different at $P<0.05$, as indicated by Conover's test. SN, soil non-grazing; SG, soil grazing; RN, root non-grazing; RG, root grazing; G, grazing; NG, non-grazing; ST, sample type.

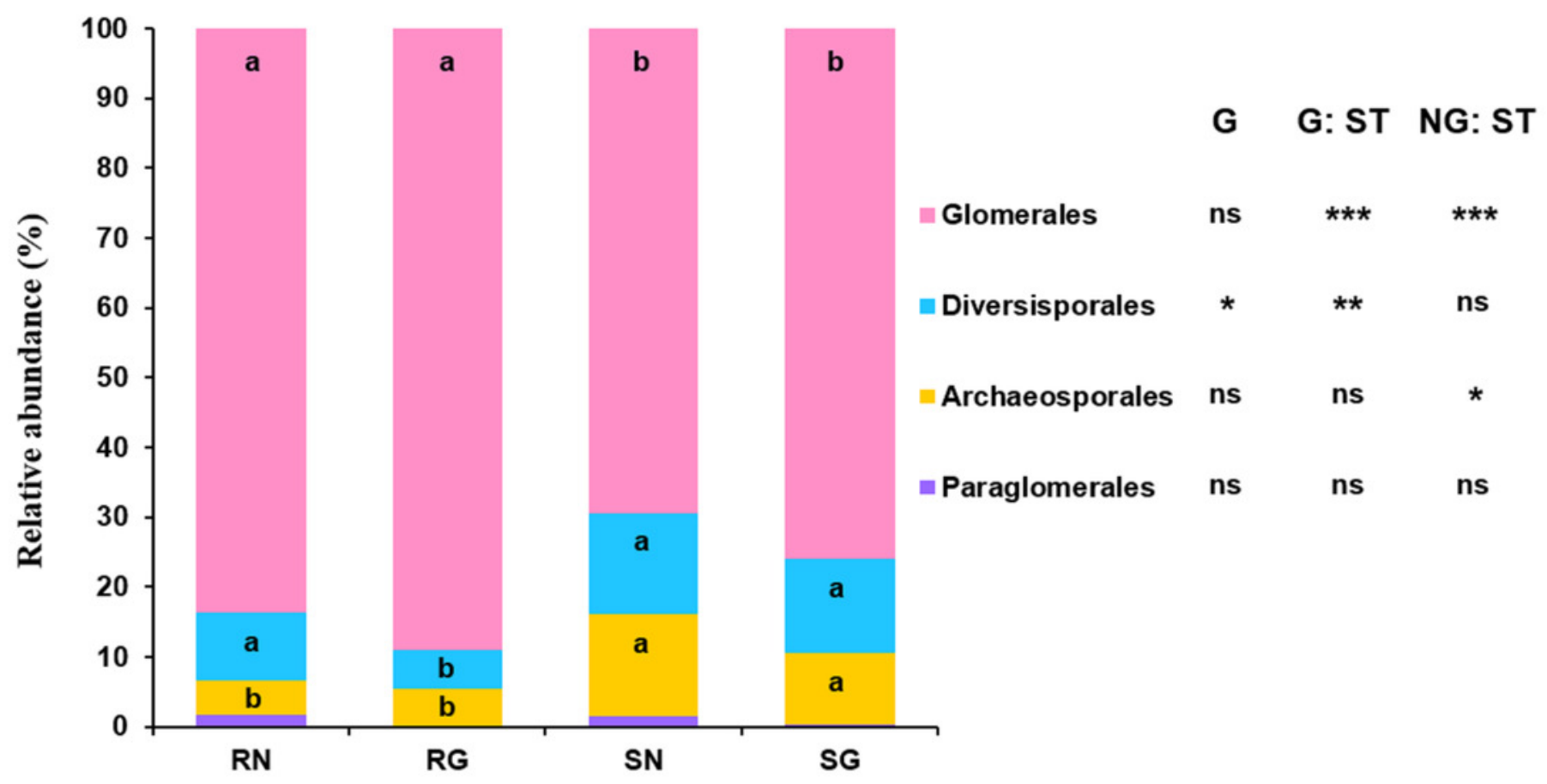




\section{Figure 5}

Redundancy analysis (RDA) biplots showing arbuscular mycorrhizal (AM) fungal community composition.

Fig. 5. Redundancy analysis (RDA) biplots showing arbuscular mycorrhizal fungal community composition in soil and roots (a), soil (b) and roots (c). Significant soil variables were presented as vectors on the RDA biplot graphs using the 'envfit' (based on 999 permutations) at $P<0.05$. SN, soil non-grazing; SG, soil grazing; RN, root non-grazing; RG, root grazing; $\mathrm{N}$, soil total nitrogen; C, soil total carbon; P, soil total phosphorus.
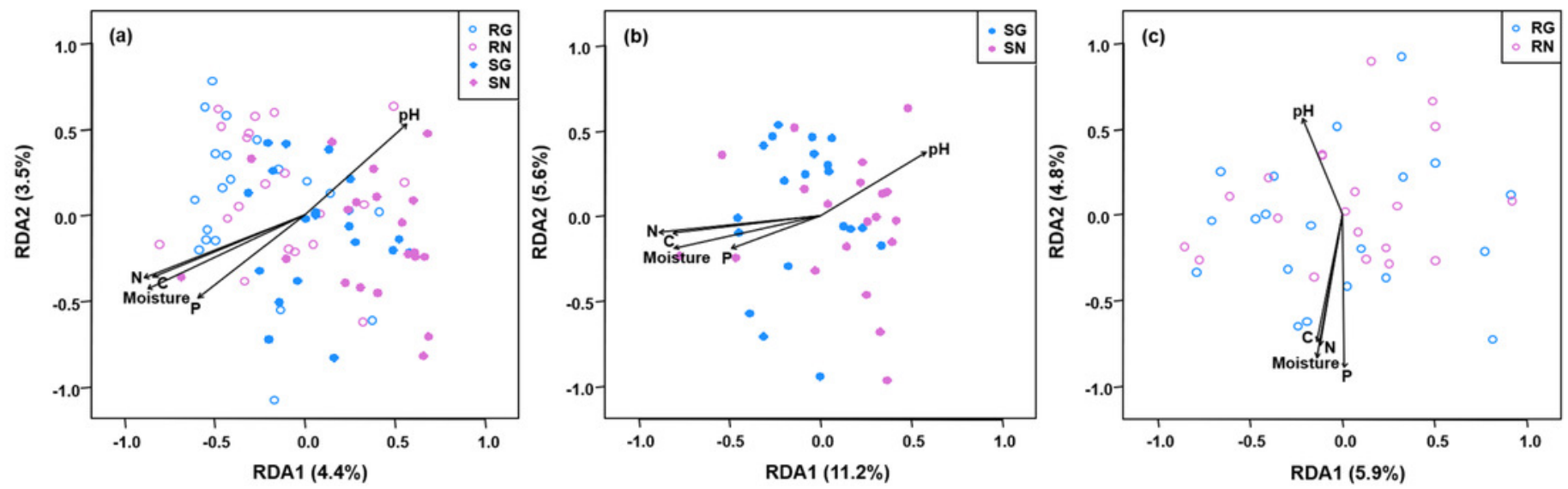


\section{Table $\mathbf{1}$ (on next page)}

Soil properties in grazing and non-grazing treatments in this study.

Table 1 Soil properties in grazing and non-grazing treatments in this study. 
1 Table 1 Soil properties in grazing and non-grazing treatments in this study.

\begin{tabular}{lll}
\hline Soil variable & Grazing & Non-grazing \\
\hline $\mathrm{pH}$ & $7.719 \pm 0.215 \mathrm{~b}$ & $7.838 \pm 0.067 \mathrm{a}$ \\
Moisture (\%) & $35.09 \pm 6.307 \mathrm{a}$ & $29.24 \pm 4.766 \mathrm{~b}$ \\
$\mathrm{~N}\left(\mathrm{~g} \mathrm{~kg}^{-1}\right)$ & $14.92 \pm 5.588 \mathrm{a}$ & $8.629 \pm 3.360 \mathrm{~b}$ \\
$\mathrm{C}\left(\mathrm{g} \mathrm{kg}^{-1}\right)$ & $202.5 \pm 76.46 \mathrm{a}$ & $111.9 \pm 36.70 \mathrm{~b}$ \\
$\mathrm{P}\left(\mathrm{g} \mathrm{kg}^{-1}\right)$ & $1.232 \pm 0.242 \mathrm{a}$ & $1.036 \pm 0.084 \mathrm{~b}$
\end{tabular}

$2 \overline{\text { Data (means } \pm \mathrm{SD} \text { ) with different letters in the same row are significantly different at } P}<0.05$, as

3 indicated by Tukey's HSD test or Conover's test. N, soil total nitrogen; C, soil total carbon; P, soil

4 total phosphorus. 


\section{Table 2 (on next page)}

The effect of grazing on easily extracted glomalin-related soil protein , total extracted GRSP, spore density and extra radical hyphal density of arbuscular mycorrhizal fungi.

Table 2 General linear model (GLM) showing the effect of grazing on easily extracted glomalin-related soil protein (EE-GRSP), total extracted GRSP (T-GRSP), spore density and extra radical hyphal $(E R H)$ density of arbuscular mycorrhizal fungi. 
1 Table 2 General linear model (GLM) showing the effect of grazing on easily extracted glomalin-

2 related soil protein (EE-GRSP), total extracted GRSP (T-GRSP), spore density and extra radical

3 hyphal (ERH) density of arbuscular mycorrhizal fungi.

\begin{tabular}{lllll}
\hline Variable & Estimate & $\mathrm{SE}$ & $\mathrm{t} / \mathrm{z}$-value & $P$-value \\
\hline EE-GRSP & -3.2506 & 0.975 & -3.334 & 0.002 \\
T-GRSP & -0.29705 & 0.03482 & -8.531 & $<0.001$ \\
Spore density & -0.54395 & 0.07252 & -7.501 & $<0.001$ \\
ERH density & -0.2562 & 0.1693 & -1.514 & 0.13 \\
\hline
\end{tabular}

4 